\title{
Leaf application of silicic acid to upland rice and corn
}

\section{Aplicação foliar de ácido silícico nas culturas do arroz e milho}

\author{
Carlos Alexandre Costa Crusciol ${ }^{1 *}$; Rogério Peres Soratto ${ }^{1}$; \\ Gustavo Spadotti Amaral Castro²; Jayme Ferrari Neto ${ }^{3}$; \\ Claudio Hideo Martins da Costa ${ }^{3}$
}

\begin{abstract}
This study aimed to evaluate the effect of Si (stabilized silicic acid, Silamol ${ }^{\circledR}$ ) leaf application on mineral nutrition and yield in upland rice and corn crops. The treatments were the control (without $\mathrm{Si}$ ) and Si foliar split spraying using $2 \mathrm{~L} \mathrm{ha}^{-1}$ of the Silamol ${ }^{\circledR}$ commercial product, with $0.8 \%$ soluble $\mathrm{Si}$ as concentrated stabilized silicic acid. Silicon leaf application increased the concentrations of K, Ca and $\mathrm{Si}$ in rice and corn leaves, the number of panicles per $\mathrm{m}^{2}$ of rice and the number of grains per ear of corn; accordingly, the Si leaf application provided a higher grain yield in both crops.
\end{abstract}

Key words: Oryza sativa, Zea mays, silicon, leaf fertilization, mineral nutrition

Resumo

Objetivou-se por meio deste trabalho avaliar o efeito da aplicação de Si (ácido silícico estabilizado - Silamol®) via foliar na nutrição e produtividade do arroz e do milho. Os tratamentos foram o controle (sem $\mathrm{Si}$ ) e aplicação parcelada de $\mathrm{Si}$ via foliar na dose total de 2

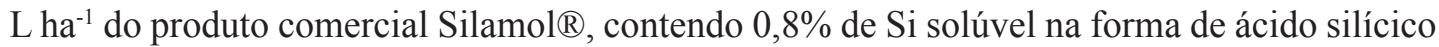
concentrado estabilizado. A aplicação de Si aumentou os teores foliares de K, Ca e Si nas culturas do arroz e milho, o número panículas por $\mathrm{m}^{2}$ do arroz e o número de grãos por espiga do milho, que proporcionou maior produtividade de grãos em ambas as culturas.

Palavras-chave: Oryza sativa, Zea mays, silício, adubação foliar, nutrição mineral

${ }^{1}$ Profs. Drs. of Department of Crop Science, College of Agricultural Sciences, São Paulo State University, UNESP, Botucatu, State of São Paulo, SP, Brazil. E-mail: crusciol@fca.unesp.br; soratto@fca.unesp.br

${ }^{2}$ Researcher of Brazilian Agricultural Research Corporation, EMBRAPA, P. O. Box 10, Macapá, AP, Brazil. E-mail: gustavo. castro@embrapa.br

${ }^{3}$ Graduate Students in Agronomy, College of Agricultural Sciences, São Paulo State University, UNESP, Botucatu, State of São Paulo, SP, Brazil. E-mail: c_hideo@hotmail.com; jaymeferrari@hotmail.com

* Author for correspondence 
Silicon ( $\mathrm{Si}$ ) improves plant growth and yield in several crop species through its indirect effects on photosynthetic and biochemical processes. These benefits are particularly evident when the plants are subjected to stress, whether the stresses are biotic, such as diseases and pests (MA; YAMAJI, 2006), or abiotic, such as water and temperature stress (ABDALLA, 2011).

Even when plant roots are in the presence of high concentrations of $\mathrm{Si}$, the absorption of the element is an active process because plants absorb Si exclusively as monosilicic acid, which is also called orthosilicic acid $\left[\mathrm{Si}(\mathrm{OH})_{4}\right]$ (MALAVOLTA; VITTI; OLIVEIRA, 1997). This monomeric form of silicic acid is found in fresh water at low concentrations $\left(<10^{-4} \mathrm{M}\right)$ and gelatinizes into silica gel at high concentrations or low $\mathrm{pH}$ (CALOMME et al., 2002). In theory, sources with Si in the form of silicic acid are stable and able to form orthosilicic acid when diluted; thus, they represent alternatives for increasing Si absorption in plants.

Si supplied through leaves can also be a viable alternative in plants. Even small amounts of the element can be used to meet the needs of the plant and/or stimulate the absorption of Si. For example, the beneficial effects of potassium silicate application include reduced incidence of rice blast (BUCK et al., 2008), improved quality of strawberry fruits (FIGUEIREDO et al., 2010) and increased grain yield in corn (SOUSA et al., 2010). Thus, leaf application of soluble Si represents an important method for supplying Si due to its effectiveness, practicability, lower usage rates and adaptability to sprayers commonly used by many producers (FIGUEIREDO et al., 2010).

Despite these advantages, there are virtually no scientific studies regarding leaf application of $\mathrm{Si}$ as a stabilized silicic acid. The present study therefore aimed to evaluate the effects of Si leaf application, in the form of stabilized silicic acid, on nutrition and grain yield of upland rice and corn crops.

Two experiments, one in rice and the other in corn, were performed in the agricultural year 2007/2008 in Botucatu, State of São Paulo, Brazil (22 ${ }^{\circ} 51^{\prime}$ S, 48 26' W, $740 \mathrm{~m}$ asl). According to Köppen's classification, the climate in the region is Cwa, which is characterized as a tropical altitude with dry winters and hot and wet summers. (LOMBARDI NETO; DRUGOWICH, 1994). Figure 1 shows the monthly average temperatures and total monthly rainfall during the experimental period. The soil in the experimental area is a Typic Hapludox (EMBRAPA, 2006). In the area where rice was grown, the soil had the following chemical properties in the arable layer (0-0.20 m depth): $18.3 \mathrm{~g} \mathrm{dm}^{-3}$ organic matter; $\mathrm{pH}\left(\mathrm{CaCl}_{2}\right): 4.2$; $\mathrm{P}$ (resin): $3.6 \mathrm{mg} \mathrm{dm}{ }^{-3}$; $\mathrm{Si}: 6.0 \mathrm{mg}$ $\mathrm{dm}^{-3} ; \mathrm{K}, \mathrm{Ca}, \mathrm{Mg}, \mathrm{Al}+\mathrm{H}$ and CEC: $1.2,22.2,8.8$, 32.1 and $64.3 \mathrm{mmol}_{\mathrm{c}} \mathrm{dm}^{-3}$, respectively; and 50\% base saturation. In the area where corn was grown, the chemical properties of the soil were as follows: $37.4 \mathrm{~g} \mathrm{dm}^{-3}$ organic matter; $\mathrm{pH}\left(\mathrm{CaCl}_{2}\right)$ : 4.6; $\mathrm{P}$ (resin): $20.9 \mathrm{mg} \mathrm{dm}^{-3}$; Si: $6.4 \mathrm{mg} \mathrm{dm}^{-3} ; \mathrm{K}, \mathrm{Ca}, \mathrm{Mg}, \mathrm{Al}+\mathrm{H}$ and CEC 1.2, 28.3, 15.4, 42.0 and $86.9 \mathrm{mmol}_{\mathrm{c}} \mathrm{dm}^{-3}$, respectively; and $52 \%$ base saturation. 
Figure 1. Monthly total rainfall ( ) and average monthly temperature (-) during the experimental period.

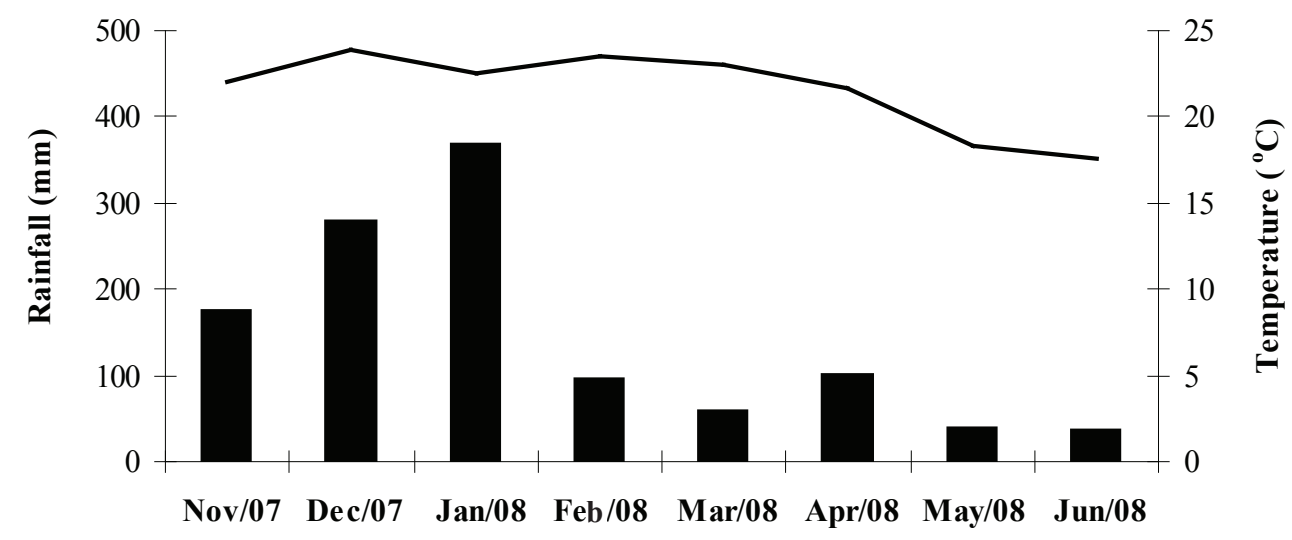

Source: Department of Natural Resources, College of Agricultural Sciences, São Paulo State University (UNESP), Botucatu, Brazil.

Both experiments had a completely randomized block design with 14 replications. Treatments consisted of a control (with no Si application) and Si leaf application, at $2.0 \mathrm{~L} \mathrm{ha}^{-1}$ of the commercial product (Silamol@). The product contained $0.8 \%$ soluble $\mathrm{Si}$ as a stabilized concentrated silicic acid that forms orthosilicic acid $\left[\mathrm{Si}(\mathrm{OH})_{4}\right]$ and disilicic acid after dilution, $0.15 \%$ Mo and $48 \%$ polyethylene glycol (PEG400). Each plot in each experiment consisted of six plant rows $5 \mathrm{~m}$ in length. The four central rows were evaluated, disregarding $0.5 \mathrm{~m}$ at both ends of the rows.

The upland rice cultivar IAC 202 was sown on November 15, 2007, within the period recommended for the crop (BRASIL, 2012), in rows spaced 0.45 $\mathrm{m}$ apart and with 70 seeds $\mathrm{m}^{-1}$. In the sowing furrow, $10 \mathrm{~kg} \mathrm{ha}^{-1} \mathrm{~N}, 80 \mathrm{~kg} \mathrm{ha}^{-1} \mathrm{P}_{2} \mathrm{O}_{5}$ and $40 \mathrm{~kg} \mathrm{ha}^{-1} \mathrm{~K}_{2} \mathrm{O}$ were applied using ammonium nitrate $(33 \% \mathrm{~N})$, simple superphosphate $\left(41 \% \mathrm{P}_{2} \mathrm{O}_{5}\right)$ and potassium chloride $(58 \% \mathrm{KCl})$, respectively. For the side dressing, $40 \mathrm{~kg} \mathrm{ha}^{-1} \mathrm{~N}$ was applied using ammonium nitrate on January 8, 2008 at the tillering stage. Propanil + Thiobencarb (1200 and $2400 \mathrm{~mL} \mathrm{ha-1}$ of a.i., respectively) were used for weed control, and two applications of Deltametrina ( $7.5 \mathrm{~g} \mathrm{ha}^{-1}$ of a.i.) were used for pest control. The fungicides Epoxiconazole + Pyraclostrobin (25 and $67 \mathrm{~g} \mathrm{ha}^{-1}$ a.i., respectively) were applied at the booting and flowering stages.
The corn hybrid simple 2B587 (Dow Agroscience) was sown on January 10, 2008, within the period recommended for the crop (BRASIL, 2012), in rows spaced $0,90 \mathrm{~m}$ apart and with 6 seeds $\mathrm{m}^{-1}$. The fertilization consisted of $30 \mathrm{~kg} \mathrm{ha}^{-1} \mathrm{~N}, 60 \mathrm{~kg} \mathrm{ha}^{-1}$ $\mathrm{P}_{2} \mathrm{O}_{5}$, and $50 \mathrm{~kg} \mathrm{ha}^{-1} \mathrm{~K}_{2} \mathrm{O}$, applied as ammonium nitrate, triple superphosphate and potassium chloride, respectively, in the sowing furrow. When the plants were at growth stage $\mathrm{V} 6,90 \mathrm{~kg} \mathrm{ha}^{-1} \mathrm{~N}$ and $60 \mathrm{~kg} \mathrm{ha}^{-1} \mathrm{~K}_{2} \mathrm{O}$ were applied using ammonium nitrate and potassium chloride, respectively. The herbicide Atrazine (2500 $\mathrm{g} \mathrm{ha}^{-1}$ of a.i.) was used for weed control, and Lambda-cialotrina + Thiamethoxam (20 and $28 \mathrm{~g} \mathrm{ha}^{-1}$ of a.i., respectively) and Espinosade (48 $\mathrm{g} \mathrm{ha}^{-1}$ of a.i.) were used for pest control.

Silicon was applied at the stages recommended by the fertilizer manufacturer. For the rice crop, three applications of $0.67 \mathrm{~L} \mathrm{ha}^{-1}$ were applied (at tillering, floral differentiation, and booting). Two applications $\left(1.0+1.0 \mathrm{~L} \mathrm{ha}^{-1}\right)$ were used for the corn crop (at the V4 and V8 stages). All applications were performed using a $\mathrm{CO}_{2}$-pressurized sprayer with a volume of $200 \mathrm{~L} \mathrm{ha}^{-1}$.

At the flowering stages of both crops, leaves from 20 plants were sampled per plot of each experiment. More specifically, the flag leaf in rice and the central third portion of the leaf at the base of the corn ears were used (CANTARELLA et al., 
1997). The samples were analyzed for macronutrient concentration ( $\mathrm{N}, \mathrm{P}, \mathrm{K}, \mathrm{Ca}, \mathrm{Mg}$ and $\mathrm{S}$ ) and $\mathrm{Si}$, according to Malavolta, Vitti and Oliveira (1997) and Korndörfer, Pereira and Nolla (2004).

The rice crop was harvested on March 27, 2008, and the yield components (number of panicles per square meter, number of spikelets per panicle, spikelet fertility, and 1000-grain weight) were determined along with grain yield. Similarly, the corn crop was harvested on June 1, 2008, and the yield components (final plant population, number of ears per plant, number of grains per ear, and 100-grain weight) were determined along with grain yield.

The data were subjected to analysis of variance, and means were compared using a t test (LSD) at a significance level of $5 \%$.
In rice, silicon application increased the concentrations of $\mathrm{K}, \mathrm{Ca}$ and $\mathrm{Si}$ in the flag leaves, and in corn leaves, the concentrations of $\mathrm{K}, \mathrm{Ca}, \mathrm{Mg}$ and $\mathrm{Si}$ increased (Table 1). These changes may be due in part to major root growth resulting from $\mathrm{Si}$ application (CARVALHO-PUPATTO et al., 2003). According to Buck et al. (2008), Figueiredo et al. (2010) and Sousa et al. (2010), silicon leaf application is a viable alternative for supplying the nutrient in plants. Leaf applications at low rates can increase nutrient concentrations beyond the quantities applied. This practice is known as complementary stimulant leaf fertilization and is indicated for use in high yield crops without nutritional deficiencies (ROSOLEM, 2002). Abdalla (2011) previously reported that applying diatomite to soil to provide Si to plants increased root growth in lupine plants under controlled greenhouse conditions.

Table 1. Concentrations of N, P, K, Ca, Mg, S, and Si in the leaf (flag leaf of rice; leaf at the base of the corn ears), yield components, and grain yield of upland rice and corn crops under Si leaf application (Botucatu, State of São Paulo, Brazil, 2008).

\begin{tabular}{|c|c|c|c|c|}
\hline \multirow[t]{2}{*}{ Variable } & Control & $\mathrm{Si}$ & F value & $\mathrm{CV}(\%)$ \\
\hline & \multicolumn{4}{|c|}{ Rice } \\
\hline $\mathrm{N}\left(\mathrm{g} \mathrm{kg}^{-1}\right)$ & 34.0 & 34.0 & $0.5^{\mathrm{ns}}$ & 6.8 \\
\hline $\mathrm{P}\left(\mathrm{g} \mathrm{kg}^{-1}\right)$ & 3.9 & 3.5 & $3.7^{\mathrm{ns}}$ & 13.5 \\
\hline $\mathrm{K}\left(\mathrm{g} \mathrm{kg}^{-1}\right)$ & $16.0 \mathrm{~b}$ & $18.0 \mathrm{a}$ & $8.0^{*}$ & 16.8 \\
\hline $\mathrm{Ca}\left(\mathrm{g} \mathrm{kg}^{-1}\right)$ & $3.7 \mathrm{~b}$ & $4.1 \mathrm{a}$ & $7.3 *$ & 15.3 \\
\hline $\operatorname{Mg}\left(\mathrm{g} \mathrm{kg}^{-1}\right)$ & 1.3 & 1.3 & $1.5^{\mathrm{ns}}$ & 17.7 \\
\hline $\mathrm{S}\left(\mathrm{g} \mathrm{kg}^{-1}\right)$ & 3.3 & 3.3 & $0.1^{\text {ns }}$ & 20.6 \\
\hline $\mathrm{Si}\left(\mathrm{g} \mathrm{kg}^{-1}\right)$ & $15.0 \mathrm{~b}$ & $18.0 \mathrm{a}$ & $10.4 * *$ & 15.0 \\
\hline Number of panicles $\mathrm{m}^{-2}$ & $107.0 \mathrm{~b}$ & $146.0 \mathrm{a}$ & $14.3 * *$ & 23.9 \\
\hline Number of spikelets panicle ${ }^{-1}$ & 139.0 & 145.0 & $0.4^{\mathrm{ns}}$ & 16.9 \\
\hline Spikelet fertility (\%) & 62.5 & 58.1 & $2.3^{\text {ns }}$ & 12.7 \\
\hline 1,000 -grain weight $(\mathrm{g})$ & 21.9 & 22.4 & $2.1^{\mathrm{ns}}$ & 4.5 \\
\hline \multirow[t]{2}{*}{ Grain yield $\left(\mathrm{kg} \mathrm{ha}^{-1}\right)$} & $1458 \mathrm{~b}$ & 2237 a & $10.4 * * *$ & 20.2 \\
\hline & \multicolumn{4}{|c|}{ Corn } \\
\hline $\mathrm{N}\left(\mathrm{g} \mathrm{kg}^{-1}\right)$ & 33.0 & 32.0 & $0.5^{\mathrm{ns}}$ & 8.1 \\
\hline$P\left(\mathrm{~g} \mathrm{~kg}^{-1}\right)$ & 2.9 & 2.7 & $1.2^{\mathrm{ns}}$ & 14.3 \\
\hline $\mathrm{K}\left(\mathrm{g} \mathrm{kg}^{-1}\right)$ & $23.0 \mathrm{~b}$ & $27.0 \mathrm{a}$ & $5.4^{*}$ & 19.1 \\
\hline $\mathrm{Ca}\left(\mathrm{g} \mathrm{kg}^{-1}\right)$ & $4.6 \mathrm{~b}$ & $6.2 \mathrm{a}$ & $7.4 *$ & 15.3 \\
\hline $\operatorname{Mg}\left(\mathrm{g} \mathrm{kg}^{-1}\right)$ & $2.6 \mathrm{~b}$ & $3.1 \mathrm{a}$ & $6.5^{*}$ & 19.9 \\
\hline $\mathrm{S}\left(\mathrm{g} \mathrm{kg}^{-1}\right)$ & 2.4 & 2.5 & $0.8^{\mathrm{ns}}$ & 19.7 \\
\hline $\mathrm{Si}\left(\mathrm{g} \mathrm{kg}^{-1}\right)$ & $25.0 \mathrm{~b}$ & $30.0 \mathrm{a}$ & $9.5^{* *}$ & 15.3 \\
\hline Plant population $\left(\mathrm{n}^{\circ} \mathrm{ha}^{-1}\right)$ & 58400 & 58500 & $0.1^{\text {ns }}$ & 5.5 \\
\hline Number of ears per plant & 0.9 & 0.9 & $0.1^{\mathrm{ns}}$ & 3.5 \\
\hline Number of grains per ear & $444 \mathrm{~b}$ & $510 \mathrm{a}$ & $19.8^{* * *}$ & 8.8 \\
\hline 100-grain weight (g) & 35.3 & 35.4 & $0.1^{\mathrm{ns}}$ & 4.2 \\
\hline Grain yield $\left(\mathrm{kg} \mathrm{ha}^{-1}\right)$ & $6697 \mathrm{~b}$ & $7098 \mathrm{a}$ & $11.0 * *$ & 5.0 \\
\hline
\end{tabular}

Means followed by the same lowercase letter within a row do not differ significantly ( $\mathrm{t}$ test, $5 \%$ ). $* * *$ and $* * *$ indicate significance levels of $5 \%, 1 \%$ and $0,1 \%$, respectively; ns, not significant.

Source: Elaboration of the authors. 
Regarding the yield components, silicon leaf application in rice increased the number of panicles per square meter by $36.4 \%$ compared to the control (Table 1). This result corroborates the findings of Ma, Miyake and Takahashi (2001), who also investigated Si application in rice crops. These results may have been due to the drought that occurred during the growth period of the rice crop (Figure 1). Si deposited onto rice husks can reduce transpiration of the panicle in both grain stages (milk grain and mature grain) up to $30 \%$ (MA; MIYAKE; TAKAHASHI, 2001) and thus ensure panicle viability. Because water deficiency promotes axillary bud dormancy, it can reduce rice tillering and affect the number of stems per square meter. If water deficiency persists until the transition period from the vegetative phase into the reproductive phase, the number of panicles per area is affected (FORNASIERI FILHO; FORNASIERI, 1993). Due to the increase in the number of panicles per area, the Si leaf application increased rice grain yield by $53.4 \%$, i.e. 13 sacks (of $60 \mathrm{~kg}$ ) or $779 \mathrm{~kg}$ $\mathrm{ha}^{-1}$, relative to the control (Table 1).

In corn, $\mathrm{Si}$ leaf application increased the number of grains per ear by $14.9 \%$ (Table 1 ). This result is most likely attributable to increased $\mathrm{Ca}$ concentration, which promotes ovule fertilization and subsequent ovule development (MALAVOLTA, 2006), and higher stress tolerance resulting from increased Si nutrition (KORNDÖRFER; PEREIRA; NOLLA, 2004). The application of Si to the leaves increased grain yield by $6 \%$, i.e. 6.7 sacks (of 60 $\mathrm{kg}$ ) or $401 \mathrm{~kg} \mathrm{ha}^{-1}$, relative to the control, which was observable as an increased number of grains per ear.

The effect of Si leaf application in rice and corn also correlated with drought tolerance in the crops at different growth stages, particularly flowering (Figure 1), as indicated by increased production and the accumulation of total sugar and proline (CRUSCIOL et al., 2009; ABDALLA, 2011). It is important to note that over the course of the study period, pests and diseases were adequately controlled, and the average temperature of $22.1{ }^{\circ} \mathrm{C}$ was not a limiting factor.

Taken together, the findings of the present study indicate that Si leaf application (stabilized silicic acid) affects nutrition and increases the grain yield of rice and corn crops.

\section{Acknowledgements}

The authors wish to acknowledge the National Council for Scientific and Technological Development $(\mathrm{CNPq})$ for an award for excellence in research to the first and second authors.

\section{References}

ABDALLA, M. M. Beneficial effects of diatomite on growth, the biochemical contents and polymorphic DNA in Lupinus albus plants grown under water stress. Agriculture and Biology Journal of North America, Milford, v. 2, n. 2, p. 207-220, 2011.

BRASIL. Ministério da Agricultura. Zoneamento Agrícola. 2012. Disponível em: <http://www.agricultura. gov.br/politica-agricola/zoneamento-agricola>. Acesso em: 18 out. 2012.

BUCK, G. B.; KORNDÖRFER, G. H.; NOLLA, A.; COELHO, L. Potassium silicate as foliar spray and rice blast control. Journal of Plant Nutrition, London, v. 31, n. 2, p. 231-237, 2008.

CALOMME, M.; COS, P.; D'HAESE, P.; VINGERHOETS, R.; LAMBERTS, L.; DE BROE, M.; VAN HOOREBEKE, C.; VANDEN BERGHE, D. Silicon absorption from stabilized orthosilicic acid and other supplements in healthy subjects. Trace Elements in Man and Animals, New York, v. 10, n. 4, p. 1111-1114, 2002.

CANTARELLA, H.; RAIJ, B. van; CAMARGO, C. E. O. Cereais. In: RAIJ, B. van. et al. Recomendações de adubação e calagem para o Estado de São Paulo. 2. ed. Campinas: IAC, 1997. p. 45-47. (Boletim técnico, 100).

CARVALHO-PUPATTO, J.G.;BÜLL, L.T.; CRUSCIOL, C. A. C.; MAUAD, M.; SILVA, R. H. Efeito da escória de alto forno no crescimento radicular e na produtividade de arroz. Pesquisa Agropecuária Brasileira, Brasília, v. 38, n. 11, p. 938-943, 2003.

CRUSCIOL, C. A. C.; PULZ, A. L.; LEMOS, L. B.; SORATTO, R. P.; LIMA, G. P. P. Effects of silicon and drought stress on tuber yield and leaf biochemical 
characteristics in potato. Crop Science, Madison, v. 49, n. 3, p. 949-954, 2009.

EMPRESA BRASILEIRA DE PESQUISA AGROPECUÁRIA - EMBRAPA. Sistema brasileiro de classificação de solos. 2. ed. Rio de Janeiro: Embrapa, 2006. $306 \mathrm{p}$.

FIGUEIREDO, F. C.; BOTREL, P. P.; TEIXEIRA, C. P.; PETRAZZINI, L. L.; LOCARNO, M.; CARVALHO, J. G. Pulverização foliar e fertirrigação com silício nos atributos físico-químicos de qualidade e índices de coloração do morango. Ciência e Agrotecnologia, Lavras, v. 34, n. 5, p. 1306-1311, 2010.

FORNASIERI FILHO D.; FORNASIERI, J. L. Manual da cultura do arroz. Jaboticabal: FUNEP, 1993. 221 p.

KORNDÖRFER, G. H.; PEREIRA, H. S.; NOLLA, A. Análise de silício: solo, planta e fertilizante. Uberlândia: GPSi-ICIAG-UFU, 2004. 34 p. (Boletim técnico, 2).

LOMBARDI NETO, F.; DRUGOWICH, M. Manual técnico de manejo e conservação de solo e água. Campinas: CATI, v. 2, 1994. 168 p.
MA, J. F.; MIYAKE, Y.; TAKAHASHI, E. Silicon as a beneficial element for crop plants. In: DATNOFF, L. E.; SNYDER, G. H.; KORNDÖRFER, G. H. (Ed.). Silicon in agriculture. The Netherland: Elsevier Science, 2001. p. 17-39.

MA, J. F.; YAMAJI, N. Silicon uptake and accumulation in higher plants. Trends in Plant Science, Amsterdã, v. 11, n. 8, p. 392-397, 2006.

MALAVOLTA, E. Elementos de nutrição de plantas. São Paulo: Agronômica Ceres, 2006. 638 p.

MALAVOLTA, E.; VITTI, G. C.; OLIVEIRA, S. A. Avaliação do estado nutricional das plantas: princípios e aplicações. 2. ed. Piracicaba: Associação Brasileira para Pesquisa da Potassa e do Fosfato, 1997. 319 p.

ROSOLEM, C. A. Recomendação e aplicação de nutrientes via foliar. Lavras: UFLA/FAEPE, 2002. 99 p.

SOUSA, J. V.; RODRIGUES, C. R.; LUZ, J. M. Q.; SOUSA, V. B. F.; CARVALHO, P. C.; RODRIGUES, T. M.; BRITO, C. H. Silicato de potássio via foliar no milho: fotossíntese, crescimento e produtividade. Bioscience Journal, Uberlândia, v. 26, n. 4, p. 502-513, 2010. 